\title{
Simulating Regional Cassava Yield Gap in Nigeria
}

\section{Amit Kumar Srivastava ( $\square$ amit@uni-bonn.de )}

Institute of Crop Science and Resource Conservation, University of Bonn, Germany https://orcid.org/0000-0001-8219-4854

\section{Thomas Gaiser}

Institute of Crop Science and Resource Conservation, University of Bonn, Germany

\section{Akinola Shola Akinwumiju}

Department of Remote Sensing and GIS, The Federal University of Technology, Akure, Nigeria

\section{Wenzhi Zeng}

State Key Laboratory of Water Resources and Hydropower Engineering Science, Wuhan University, China

\section{Andrej Ceglar}

Joint Research Centre of the European Commission, Food security, Ispra, Italy

\section{Kodjovi Senam Ezui}

African Plant Nutrition Institute, Nairobi, Kenya

\section{Frank Ewert}

Institute of Crop Science and Resource Conservation, University of Bonn, Germany

\section{Adedeji Adelodun}

Department of Marine Science and Technology, Akure, Nigeria

\author{
Abass Adebayo \\ Technologies for African Agricultural Transformation, IITA, Tanzania \\ Jumoke Sobamowo \\ West African Science Service Center on Climate Change and Adapted Land Use, Accra, Ghana \\ Manmeet Singh \\ Indian Institute of Tropical Meteorology, Pune, India \\ Jaber Rahimi \\ Institute of Meteorology and Climate research, KIT, Garmisch-Partenkirchen, Germany
}

\section{Research Article}

Keywords: Nitrogen, Water, Climate, Potential yield, Actual yield

Posted Date: January 11th, 2022

DOI: https://doi.org/10.21203/rs.3.rs-1244050/v1 
License: (c) (i) This work is licensed under a Creative Commons Attribution 4.0 International License. Read Full License 
Simulating Regional Cassava Yield Gap in Nigeria

\section{Amit Kumar Srivastava*}

Institute of Crop Science and Resource Conservation, University of Bonn, Katzenburgweg 5, D-53115, Bonn,

Germany. Tel: +49 228-73-2881; Email: amit.srivastava@uni-bonn.de

Thomas Gaiser

Institute of Crop Science and Resource Conservation, University of Bonn, Katzenburgweg 5, D-53115, Bonn,

Germany. Tel: +49 228-73-2050; Email: tgaiser@uni-bonn.de

Akinola Shola Akinwumiju

Department of Remote Sensing and GIS, The Federal University of Technology, Akure, Nigeria.

Tel.: +23 4803-4445-487; Email: asakinwumiju@futa.edu.ng

Wenzhi Zeng

16 State Key Laboratory of Water Resources and Hydropower Engineering Science, Wuhan University, Wuhan 430072, China; Email: zengwenzhi1989@outlook.com

Andrej Ceglar

Joint Research Centre of the European Commission, Food security, Via Enrico Fermi 2749, 21027 Ispra, Italy;

Tel: +39 033278-6256; Email: Andrej.CEGLAR@ec.europa.eu

Kodjovi Senam Ezui

African Plant Nutrition Institute (APNI), ICIPE-Compound, Nairobi, Kenya

Tel: +254-702-133-859; Email: g.ezui@apni.net

Frank Ewert

Institute of Crop Science and Resource Conservation, University of Bonn, Katzenburgweg 5, D-53115, Bonn,

Germany. Tel: +49 228-73-2041; Email: frank.ewert@uni-bonn.de

Adedeji Adelodun

Department of Marine Science and Technology, The Federal University of Technology, Akure, Nigeria.

Tel.: +23 4090-5548-7919; Email: aaadelodun@futa.edu.ng

Abass Adebayo

36 Technologies for African Agricultural Transformation (TAAT), International Institute of Tropical Agriculture, 
42

43 West African Science Service

45

46

47

48

49

50

51

52

53

54

55

56

57

58

59

60

61

62

63

64

65

66

67

68

69

70

71

72

73

74

75

76

77

78

79

80

81

82

83

84

85

86

87 
91 Cassava production is essential for food security in Sub-Saharan Africa and serves as a major calorie- intake source in Nigeria. Here we use a crop model, LINTUL5, embedded into a modeling framework SIMPLACE to estimate potential cassava yield gaps $(\mathrm{Yg})$ in 30 states of Nigeria. Our study of climate parameter influence on the variability of current and potential yields and $\mathrm{Yg}$ shows that cumulative radiation and precipitation were the most significant factors associated with cassava yield variability $(p=0.01)$. The cumulative $Y g$ mean was estimated as $18202 \mathrm{~kg} \cdot \mathrm{ha}^{-}$ ${ }^{1}$, with a maximum of $31207 \mathrm{~kg} \mathrm{ha}^{-1}$ in Kano state. Across the states, nutrient limitation accounts for $55.3 \%$ of the total cassava yield gap, while the remaining $44.7 \%$ is attributed to water limitation. The highest untapped waterlimited yields were estimated in States, such as Bauchi, Gombe, and Sokoto, characterized by the short rainy season. Conclusively, the current cassava yield levels can be increased by a factor of five through soil fertility enhancement and with irrigation, particularly in semi-arid regions. 


\section{Introduction}

139 Cassava (Manihot esculenta) is one of the primary food sources in Sub-Saharan Africa (SSA), crucial to food 140 security and the economy under its diverse applications (Rahman and Awerije, 2016; De Souza et al., 2017; 141 Echebiri and Edaba, 2008). Nigeria, the largest cassava root-producing nation globally ${ }^{[4]}$, harvests more than 59

142 Mt of fresh cassava roots annually (FAOSTAT, 2021). Most increases in production in the last 26 years (1994-

143 2019) have been attained by improving cassava varieties and expanding the land area for cassava cultivation 144 (FAOSTAT, 2021; Ugwu, 1996). However, the existing literature suggests that the average cassava root yield 145 from 1965 to $2017\left(7000-12000 \mathrm{~kg} \cdot \mathrm{ha}^{-1}\right)$ was still below its potential productivity (Cock et al., 1979; IITA, 146 2005). Therefore, since the land estimates for cropland expansion in SSA are also contested (Chamberlain et al., 147 2014), existing cropland must produce substantially more significant quantities than the current yield levels (de 148 Araújo Visses et al., 2018).

149 Results from on-station and on-farm research indicate that in some regions, despite having favourable weather 150 conditions, a sizeable exploitable gap exists between current and achievable yields under ideal agronomic 151 management conditions (Ayoola and Makinde, 2007; Bamidele et al., 2008; Eke-Okoro and Njoku, 2012). On the 152 other hand, strong responses have been estimated in the dry matter (DM) yield changes under N, P, and K fertilizers 153 application (2-18, 3-16, and 3-22 t·DM $\cdot$ ha $^{-1}$, respectively) (Adiele et al., 2020) in different agro-ecological zones 154 of Nigeria. Thus, estimating the yield gaps (Yg) in Nigeria is essential to indicate the most important crop to 155 prioritize, limiting factors for production, and identifying the Yg hotspots. Secondly, these assessments may help 156 set agendas in policy development and research prioritization where current information is scarce.

157 The Yg of a crop grown in a particular location and cropping system is defined as the difference between the yield 158 under optimum management and the average yield achieved by farmers (Lobell et al., 2019). Yield under optimum 159 control is labelled as potential yield (Yp) under irrigated conditions or water-limited yield (Yw) under rainfed 160 conditions (Van Ittersum et al., 2013; Evans, 1993). Yp is location-specific because of the climate, but in theory, 161 it is independent of soil properties, assuming that the water and nutrients required can be added through 162 management. Thus, Yp is the most relevant benchmark for irrigated systems in locations without significant soil 163 constraints, whereas it is Yw for rainfed crops (Van Ittersum et al., 2013). Hence, Yp and Yw are based on optimum 164 planting dates, planting density, and region-specific crop variety. These factors are crucial to determining the 165 feasible growth duration, particularly in tropical climatic conditions where two or three crops are produced yearly 166 and simultaneously.

167 Site-specific simulations of Yp or Yw (using crop growth simulation models) are suggested as the most reliable 168 tools for estimating Yp or Yw and Yg of specific crops within a defined cropping system because these models 169 account for the interactions among weather, soils, and management. Therefore, they capture spatial and temporal 170 variations in Yp and Yw, which other methods could not (van Bussel et al., 2015). To increase food production, 171 identifying the regions with untapped production capacity is highly important, and this can be achieved by 172 quantitatively and spatially estimating Yg. This approach requires that we consider the spatial variation in the 173 environment and the production system. As a result, this study (i) evaluates the performance of the LINTUL5 crop 174 model for simulating the growth and development of cassava on the field at the state level in Nigeria, and (ii) identifies geospatial gradients of meteorological factors and the effect of climate on cassava yields and Yg. 


\section{Materials and methods}

\subsection{Dataset for model calibration at field scale}

181 For LINTUL5 crop model calibration at the field scale, cassava yields $\left(\mathrm{kg} \cdot \mathrm{ha}^{-1}\right)$, above-ground biomass $\left(\mathrm{kg} \cdot \mathrm{ha}^{-1}\right)$, 182 and fertilizer application (N, P, K) of five varieties viz.: TME419, Oko-iyawo, TMS91/02324, TMS96/1632, and

183 TMS98/0505 (from International Institute of Tropical Agriculture, IITA, Ibadan, Nigeria) were collected from

184 Ikenne experimental site in 2015. This site is humid, with rainy and dry seasons spanning April - November and

185 December - March, respectively. The average annual precipitation at Ikenne is $1517 \mathrm{~mm}$, while the average

186 monthly temperature ranges from $23^{\circ} \mathrm{C}$ in July to $32^{\circ} \mathrm{C}$ in February. The soil physicochemical properties of the 187 experimental site are summarized in Table 1. The cassava planting and harvesting dates at Ikenne were September 1889 9, 2014, and September 7, 2015, respectively.

189 Table 1. Physicochemical characteristics of the soil at the Ikenne experimental site.

\begin{tabular}{|c|c|c|}
\hline \multirow{2}{*}{$\begin{array}{l}\text { Characteristics } \\
\text { Soil depth (cm) }\end{array}$} & \multicolumn{2}{|c|}{ Ikenne } \\
\hline & $0-15$ & $15-30$ \\
\hline $\mathrm{pH}\left(\mathrm{H}_{2} \mathrm{O}\right)$ & 5.7 & 5.8 \\
\hline $\mathrm{OC}\left(\mathrm{g} \cdot \mathrm{kg}^{-1}\right)$ & 12.3 & 9.3 \\
\hline $\mathrm{N}\left(\mathrm{g} \cdot \mathrm{kg}^{-1}\right)$ & 0.98 & 0.74 \\
\hline $\mathrm{P}\left(\mathrm{mg} \cdot \mathrm{kg}^{-1}\right)$ & 3.63 & 1.57 \\
\hline \multicolumn{3}{|c|}{ Exchangeable Cations (cmol·kg $\left.{ }^{-1}\right)$} \\
\hline $\mathrm{Ca}$ & 3 & 2.74 \\
\hline $\mathrm{Mg}$ & 0.81 & 0.88 \\
\hline K & 0.08 & 0.16 \\
\hline $\mathrm{Na}$ & 0.07 & 0.07 \\
\hline \multicolumn{3}{|c|}{ Exchangeable micronutrients $\left(\mathrm{cmol} \cdot \mathrm{kg}^{-1}\right)$} \\
\hline $\mathrm{Zn}$ & 0.3 & 0.09 \\
\hline $\mathrm{Cu}$ & $<0.01$ & $<0.01$ \\
\hline $\mathrm{Mn}$ & 0.13 & 0.14 \\
\hline $\mathrm{Fe}$ & 0.59 & 0.81 \\
\hline \multicolumn{3}{|c|}{ Particle size distribution $\left(\mathrm{g} \cdot \mathrm{kg}^{-1}\right)$} \\
\hline Gravel content $(\%)$ & $2-5 \%$ & $10-15 \%$ \\
\hline Sand & 730 & 710 \\
\hline Silt & 60 & 60 \\
\hline Clay & 210 & 230 \\
\hline Textural class & Sandy clay loam & Sandy clay loam \\
\hline
\end{tabular}




\subsection{Data and crop-model setup at states level}

\section{3}

194

195

196

197

198

\subsubsection{Climate and Soil data}

The climate data used in this study consists of a daily time series from 1995 to 2019. It includes climate variables required for agricultural modelling (e.g., solar radiation $\left(\mathrm{W} / \mathrm{m}^{2}\right)$, precipitation $(\mathrm{mm})$, minimum and maximum temperature $\left({ }^{\circ} \mathrm{C}\right)$. They were obtained from the ERA5-Land offline land surface re-run of ECMWF's (European Centre for Medium Range Weather Forecasts) latest climate product (ECMWF, 2019). The average precipitation, potential evapotranspiration, solar radiation, minimum temperature, maximum temperature, and the mean temperature during the cassava growing season of 1995 - 2019 in 30 states of Nigeria are shown in Figure S1.

The relevant soil parameters for each soil layer (i.e., sand, silt, clay, gravel content, cation exchange capacity, $\mathrm{pH}$, organic carbon, and bulk density) were extracted from African soil property maps at $1 \mathrm{~km} \times 1 \mathrm{~km}$ resolution (http://www.isric.org/data/soil-property-maps-africa-1-km). Other parameters, such as soil water at field capacity, wilting point, saturation point, and Van-Genuchten parameter, were also computed (Rawls et al., 1993). The soil properties for the entire region are depicted in Figure S2.

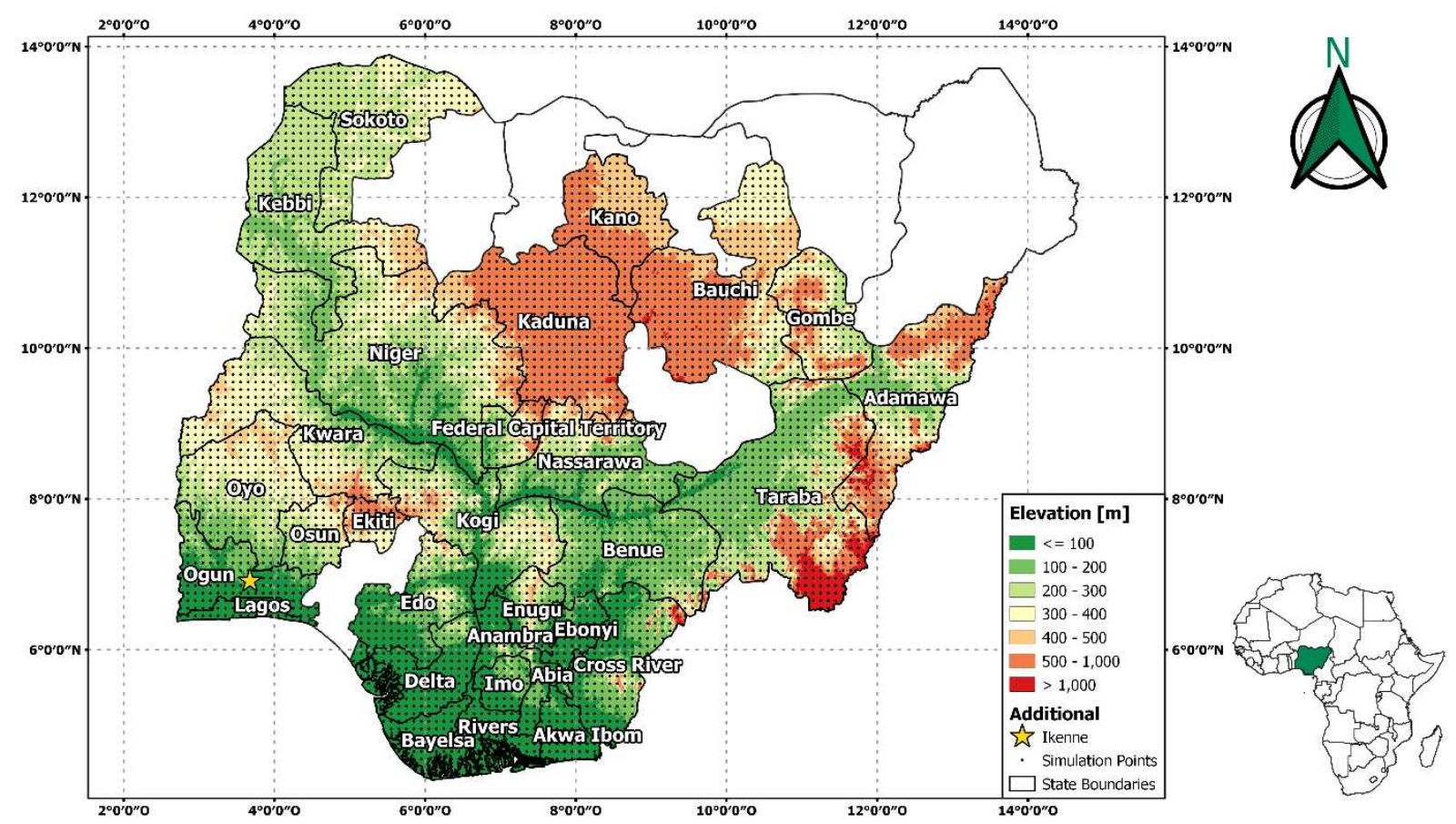

206 Figure 1. Nigeria map highlighting the simulation units of 30 states and Ikenne experimental site.

\subsubsection{Crop yield and management data}

208 State-level cassava yield data $\left(\mathrm{kg} \cdot \mathrm{ha}^{-1}\right)$ from 1995 to 2014 for 30 states (out of the 36 states) in Nigeria were 209 obtained from the IITA, Ibadan, Nigeria. The remaining six states were excluded due to either lack of data and/or 210 lack of consistencies in the available data. Because no significant trend was observed in the crop yield data (e.g., 
211 due to technological developments) from 1995 to 2014, de-trending was not applied. The cassava sowing period

212 was extracted from the crop calendar database (FAO, 2010).

\section{$213 \quad$ 2.2.3. Crop simulation}

214 Crop Yp and Yw were simulated from 1995 to 2019 using LINTUL5 (Addiscott and Whitmore, 1991) embedded 215 into the modelling framework SIMPLACE (Scientific Impact Assessment and Modelling Platform for Advanced 216 Crop and Ecosystem Management) (Gaiser et al., 2013). The applied LINTUL5 version has been used extensively 217 for cropping systems analysis in SSA (Srivastava et al., 2020, 2019, 2017; Faye et al., 2018; Trawally et al., 2015). 218 The model simulated potential yield and biomass under conditions where the crop growth is driven only by solar 219 radiation and temperature, i.e., without considering water stress, nutrient stress, abiotic stress, diseases, and other 220 factors (Wolf, 2012).

221 Water stress occurs when the available soil water is between a defined critical point and wilting point or higher than the field capacity (i.e., waterlogged). The critical point is a crop-specific value (Allen et al., 1998) that depends on crop development, soil water tension, and potential transpiration. Water, nutrients (NPK), temperature, and radiation stresses restrict the daily accumulation of biomass, root growth, and yield. To simulate the temporal dynamics of a cropping system, the model was embedded into a general modelling framework, SIMPLACE. Therefore, the SIMPLACE $<$ LINTUL5-SLIM $>$ solution of the modeling platform was used in this study.

The default cassava crop parameter set for LINTUL5 was used as a starting point to establish a new parameter set for the cassava varieties used for this study. A plausible range over which they vary was obtained from the literature (Ezui et al., 2018) for the crop parameters. We established a set containing all the model parameters and evaluated

230 it by comparing the simulated yields and the phenology to the corresponding observations by systematic sampling.

231 The systematic sampling and evaluation were performed for the entire parameter space of all variables before 232 choosing the parameter set with the smallest mean residual error. As a measure of accuracy between the statistical 233 data and simulated values, the mean relative error $\left(\mathrm{MR}=\frac{1}{n} \sum_{i=1}^{n}\left(\frac{S_{i}-O_{i}}{O_{i}}\right)\right)$, the mean residual error ( $\mathrm{ME}=$ $234 \frac{1}{n} \sum_{i=1}^{n}\left(S_{i}-O_{i}\right)$ ), and root mean square error (RMSE $\left.=\sqrt{\frac{1}{n} \sum_{i=1}^{n}\left(S_{i}-O_{i}\right)^{2}}\right)$ ) were used, where $\mathrm{n}$ is the sample 235 number, $O_{i}$ is the observed yield and $S_{i}$ is the simulated yield. The ME value of zero indicates no systematic bias 236 between simulated and measured values. The MR shows the mean magnitude of the error related to the observed 237 value; the smaller the value, the smaller the difference between simulated and measured values. Whereas, RMSE 238 is the standard deviation of the residuals (prediction errors).

\subsubsection{Definition and statistical analysis of spatial and temporal variability}

241 a. Aggregation of weather variables and model outputs:

242 The crop model was run at $1 \mathrm{~km}$ spatial resolution, corresponding to the spatial resolution of the soil input data, 243 for each simulation unit (Figure 1), defined as a combination of soil characteristics, climate, and crop management 244 data. Cassava yields from each state's simulation units were averaged, taking the harvested area of cassava crop 245 into account, sourced from SPAM (Spatial Production Allocation Model) harvest areas dataset (Yu et al., 2010) to 246 obtain a representative value per state per year. To appraise the spatial variability of cassava in all the states, the 
coefficient of variation (CV) was calculated for the estimated weather variables (precipitation, potential evapotranspiration, solar radiation, minimum temperature, maximum temperature) within the crop growth period over the simulation period.

b. Yield-gap estimation and statistical analysis:

We define the ( $\mathrm{Y}_{\mathrm{p}}$, potential yield) as the yield achieved for the crop in a given state under optimal water and nutrient levels, meaning that the crop experienced no stress. Similarly, the water-limited (rainfed) potential yield $\left(\mathrm{Y}_{\mathrm{w}}\right)$ is the yield achieved for the crop in a given state under the optimal nutrient level but with no irrigation. The observed (i.e., farmer's yield) average yield $\left(\mathrm{Y}_{\mathrm{o}}\right)$ is assumed as the water-limited and non-optimal nutrient levels $(\mathrm{N}, \mathrm{P}$, and $\mathrm{K}$ ) since the cropping system in Nigeria is characterized by rainfed and low-input agriculture. Additionally, continuous cassava cultivation on the same piece of land results in intense depletion of soil fertility and consequent reduction in yield quantity (Sarr et al., 2013; Edet et al., 2013). Based on the above definitions, YG was estimated as follows:

Multiple linear regressions were used to explain the relationship between the cassava yield (dependent variable) and the climate variables (independent variables), namely precipitation, minimum and maximum temperature, and solar radiation in the crop growing season (Figure S1). As there were only four explanatory variables, the complete statistical model was applied.

\section{Results}

\subsection{Model calibration and evaluation}

271 Compared to the observed cassava yields, the simulated yield under fertilized conditions was overestimated by

$272 \quad 1.0 \%-7.4 \%$ across the five cassava varieties, except for Oko-Iyawo, with a $0.7 \%$ yield underestimation (Table 2).

273 Under unfertilized conditions, the simulated yields were overestimated by $1.2 \%-5 \%$ and underestimated by $0.6 \%$

274 for TME419. The above-ground biomass under fertilized conditions was also overestimated by $7.8 \%$ except for

275 Oko-Iyawo, with 1.4\% under-estimation. Also, under unfertilized conditions, the over-estimation ranged between

$276 \quad 0.3 \%$ and $5.7 \%$, excluding TME419 where $0.9 \%$ under-estimation ensued (Table 2).

277 The model performed well in capturing the spatial and temporal yield variability. The average simulated yield

278 (average over the 20 study years) across the states was overestimated by $6.9 \%$ compared to the observed yields 279 with an RMSE of $478 \mathrm{~kg} \cdot \mathrm{ha}^{-1}$ and $\mathrm{R}^{2}=0.89$ (Figures $2 \mathrm{a}$ and $2 \mathrm{~b}$ ). The simulated yield within the 20 years of 280 simulation (1995-2014) compared to the observed yields was overestimated by $5.5 \%$ with an RMSE of $407 \mathrm{~kg} \cdot \mathrm{ha}^{-}$ 281 (Figure 3). 
282 Table 2. Observed and simulated yield dry matter and above-ground biomass (in ' $000 \mathrm{~kg} \cdot \mathrm{ha} \mathrm{C}^{-1}$ ), mean error (ME, 283 in ' $000 \mathrm{~kg} \cdot \mathrm{ha}^{-1}$ ), and mean residual error (in \%) under control (unfertilized) and fertilized conditions of the five 284 cassava varieties at Ikenne experimental site, Nigeria.

\begin{tabular}{|c|c|c|c|c|c|c|c|c|c|}
\hline \multirow[t]{2}{*}{ Varieties } & & \multicolumn{2}{|r|}{ Fertilized } & \multirow[b]{2}{*}{$\begin{array}{c}\text { ME } \\
\text { ('000 kg.ha-1) }\end{array}$} & \multirow[b]{2}{*}{$\begin{array}{l}\mathrm{MR} \\
(\%) \\
\end{array}$} & \multicolumn{2}{|r|}{ Control } & \multirow[b]{2}{*}{$\begin{array}{c}\text { ME } \\
\text { ('000 kg-ha-1) }\end{array}$} & \multirow[b]{2}{*}{$\begin{array}{l}\mathrm{MF} \\
(\% \\
\end{array}$} \\
\hline & & $\begin{array}{c}\text { Observed } \\
\text { ('000 kg.ha-1) }\end{array}$ & $\begin{array}{c}\text { Simulated } \\
\text { ('000 kg.ha-1) }\end{array}$ & & & $\begin{array}{c}\text { Observed } \\
\text { ('000 kg.ha-1) }\end{array}$ & $\begin{array}{c}\text { Simulated } \\
\text { ('000 kg.ha-1) }\end{array}$ & & \\
\hline \multirow[t]{2}{*}{ TME419 } & Yield & 5.40 & 5.54 & 0.14 & 2.6 & 3.30 & 3.28 & 0.02 & -0.6 \\
\hline & Above-ground Biomass & 9.20 & 9.35 & 0.15 & 1.6 & 5.60 & 5.55 & 0.05 & -0.9 \\
\hline \multirow[t]{2}{*}{ Oko-iyawo } & Yield & 4.40 & 4.37 & -0.03 & -0.7 & 2.50 & 2.53 & -0.03 & 1.2 \\
\hline & Above-ground Biomass & 7.70 & 7.59 & -0.11 & -1.4 & 4.40 & 4.44 & -0.04 & 0.9 \\
\hline \multirow{2}{*}{ TMS91/02324 } & Yield & 6.20 & 6.26 & 0.06 & 1.0 & 3.30 & 3.46 & -0.16 & 4.8 \\
\hline & Above-ground Biomass & 9.30 & 9.30 & 0.00 & 0.0 & 4.90 & 5.18 & -0.28 & 5.7 \\
\hline \multirow[t]{2}{*}{ TMS96/1632 } & Yield & 6.40 & 6.54 & 0.14 & 2.2 & 3.40 & 3.57 & -0.17 & 5.0 \\
\hline & Above-ground Biomass & 9.70 & 9.74 & 0.04 & 0.4 & 5.20 & 5.35 & -0.15 & 2.9 \\
\hline \multirow[t]{2}{*}{ TMS98/0505 } & Yield & 7.40 & 7.95 & 0.55 & 7.4 & 4.30 & 4.40 & -0.10 & 2.3 \\
\hline & Above-ground Biomass & 11.60 & 12.50 & 0.90 & 7.8 & 6.80 & 6.82 & -0.02 & 0.3 \\
\hline
\end{tabular}

(a)

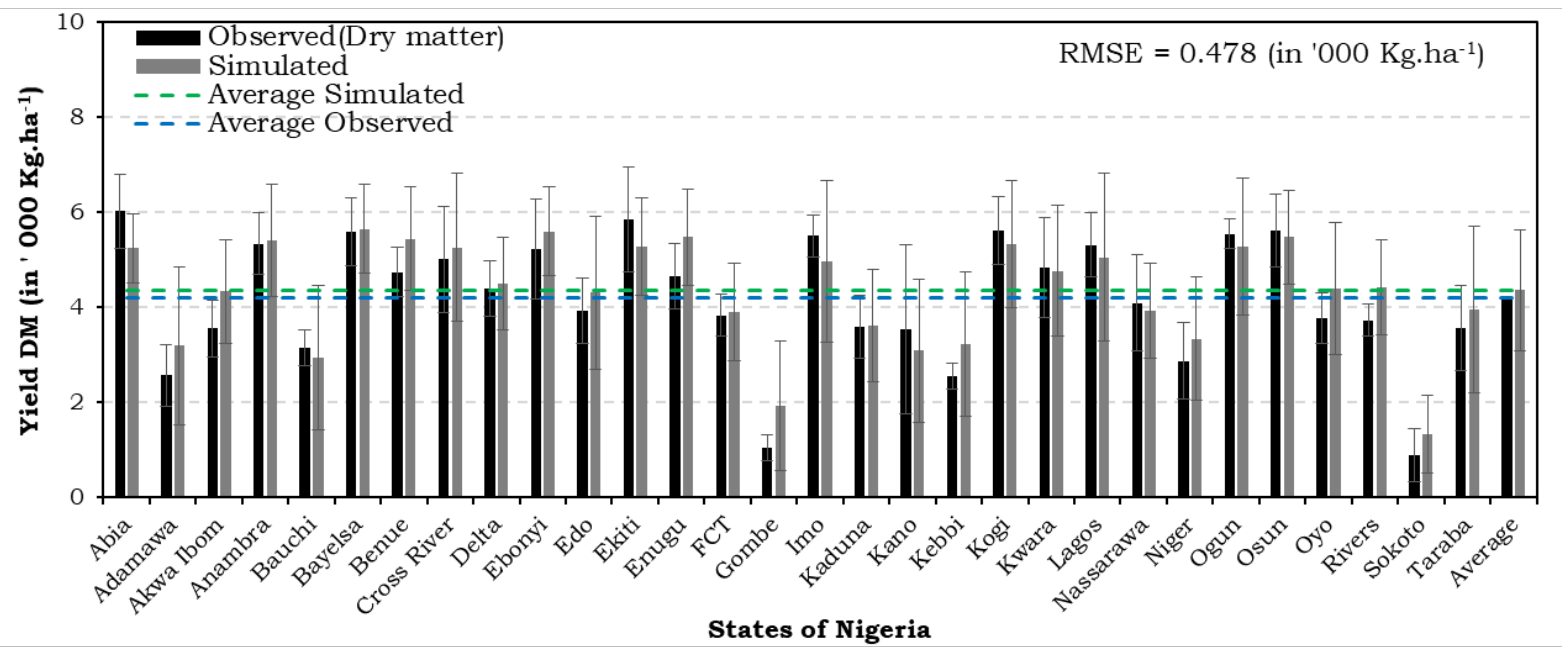

(b)

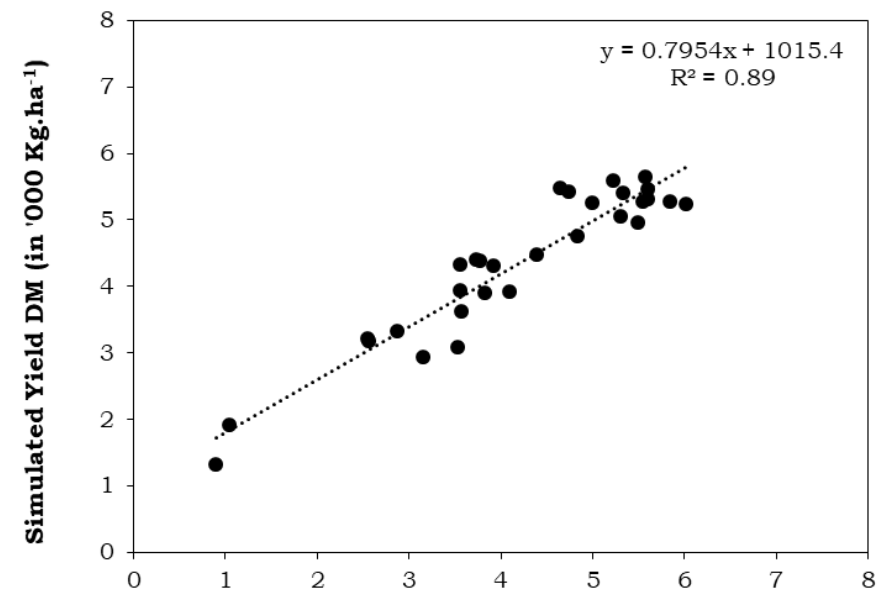

Observed Yield DM (in '000 Kg.ha-1) 
Figure 2. Simulated (water and nutrient-limited) versus observed (farmer's yield) cassava yield (in '000 kg.ha-1) averaged over 20 years from 1995-2014 (a) and 1:1 graph across the 30 states (b) in Nigeria.

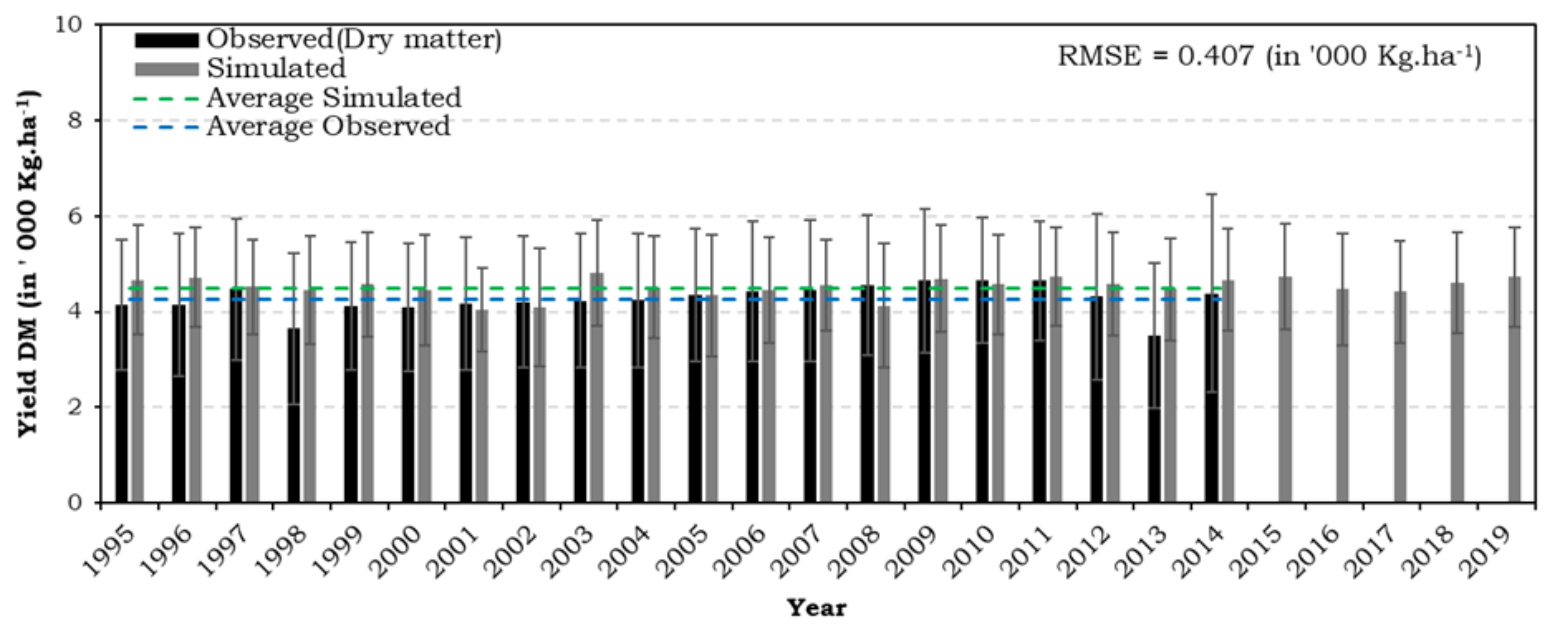

Figure 3. Simulated (water and nutrient-limited) versus observed (farmer's yield) cassava yield (in '000 kg.ha-1) for 20 years from 1995-2015 averaged over 30 states in Nigeria.

\subsection{Observed, simulated potential $\left(\mathrm{Y}_{\mathrm{p}}\right)$, and simulated water-limited $\left(\mathrm{Y}_{\mathrm{w}}\right)$ cassava yield}

The cassava's mean $Y_{p}$ and $Y_{w}$ were 22390 and $14251 \mathrm{~kg} \cdot \mathrm{ha}^{-1}$ in the 30 states from 1995 to 2019 . The $\mathrm{CV}$ in the simulated potential yields ranged from $2.1 \%$ to $4.7 \%$. For water-limited potential yield simulations, the $\mathrm{CV}$ varied from $2.9 \%$ to $32.2 \%$ across the states. In addition, the mean $Y_{p}$ and mean $Y_{w}$ ranged from 17479 to $34731 \mathrm{~kg} \cdot \mathrm{ha}^{-1}$ and 2944 (Sokoto State) to $19498 \mathrm{~kg} \cdot \mathrm{ha}^{-1}$ (Imo State), respectively (Figure 4). However, the observed yields $\left(\right.$ mean $\left.=4190.5 \mathrm{~kg} \cdot \mathrm{ha}^{-1}\right)$ ranged between 892.8 and $6010 \mathrm{~kg} \cdot \mathrm{ha}^{-1}$ (Figure 2a). The $\mathrm{Y}_{\mathrm{p}}$ increased with latitude, having the highest values of 34731, 33981, and $28118 \mathrm{~kg} \cdot \mathrm{ha}^{-1}$ in Kano, Bauchi, and Kaduna, respectively. While, the $\mathrm{Y}_{\mathrm{w}}$ increased with the lower latitudes, with the highest yield located in the Southeastern States (such as Imo (19498 $\left.\mathrm{kg} \cdot \mathrm{ha}^{-1}\right)$ and Akwa Ibom (18015 kg $\left.\cdot \mathrm{ha}^{-1}\right)$.

Multiple regression analysis (Table 3) shows that the spatial variability in the observed cassava yields across the 30 states correlated significantly with radiation $(p=0.01)$ and precipitation $(p<0.01)$ within the crop-growth period. The actual yield (simulated) also correlated significantly with radiation $(p=0.01)$ and precipitation ( $p=0.01)$ within the same period $\left(\mathrm{R}^{2}=0.76\right)$. The $\mathrm{Y}_{\mathrm{w}}$ and $\mathrm{Y}_{\mathrm{p}}$ significantly correlated with radiation $(p<0.05)$, having an $\mathrm{R}^{2}$ value of 0.84 and 0.91 , respectively. Likewise, the simulated estimation of the total yield gap and water-limited yield gap showed a highly significant correlation $(p<0.01)$ with the precipitation and radiation amount during the crop-growth period with $\mathrm{R}^{2}=0.95$ and 0.98 , respectively. The maximum temperature within the crop-growth period was also significantly correlated with the water-limited yield gap (Table 3 ). The actual yield gap was not significantly correlated with any of the dependent variables, i.e., radiation, maximum and minimum temperature, and precipitation. Similar results are shown with the nonlinear Random forest algorithm 

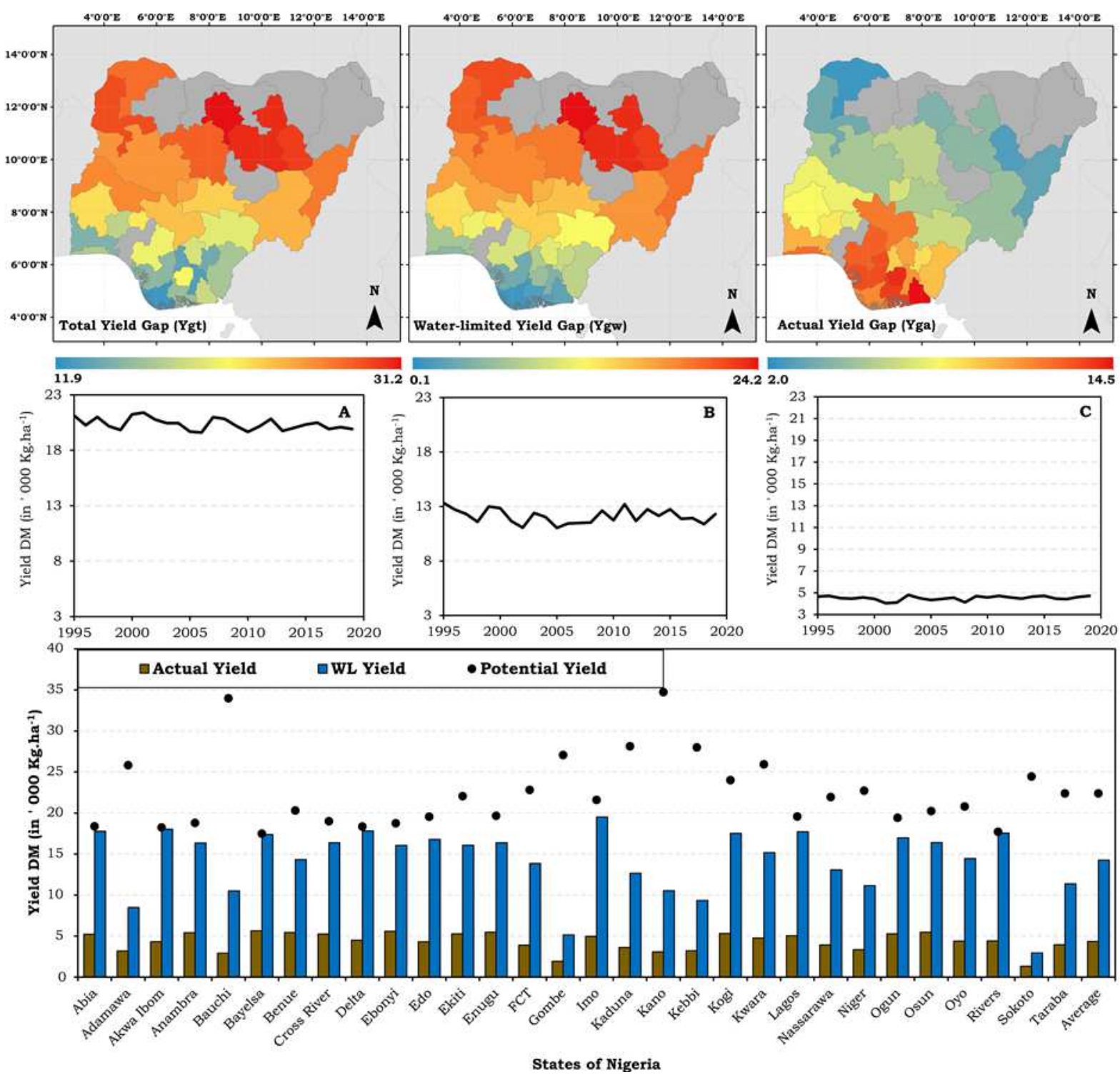

States of Nigeria

317 Figure 4. Spatial analysis of total yield gap, water-limited yield gap, and actual yield gap across the 30 states from 3181995 to 2019. Figures A, B, and C pertain to the temporal variability in simulated cassava yield under potential, water-limited, and actual conditions, respectively. The figure at the bottom (last row) illustrates the simulated value average over 20 years of actual yield, water-limited (WL) yield and the potential yield across the 30 states of Nigeria.

\subsection{Cassava yield gaps}

323 The difference between the farmers' potential yield and the observed yield represents the exploitable yield gap. This gap is becoming smaller as farmers improve their agronomic management practices, e.g., increasing fertilizer or irrigation use or improved cultivars having higher potential yields. Therefore, the total yield gap can be divided into two parts: yield reduction due to water stress and yield reductions due to other factors such as nutrient stress, diseases, insect pest, and others. On average, for the 30 states, the total yield gap $\left(\mathrm{YG}_{\mathrm{t}}\right)$ was $18202 \mathrm{~kg} \cdot \mathrm{ha}^{-1}$, about $81.2 \%$ of the average simulated potential yield $\left(\mathrm{Y}_{\mathrm{p}}\right)$. Across the states, $\mathrm{YG}_{\mathrm{t}}$ ranged from $11904 \mathrm{~kg} \cdot \mathrm{ha}^{-1}$ in Bayelsa 
to a maximum of $31207 \mathrm{~kg} \cdot \mathrm{ha}^{-1}$ in the Kano State (Figure 4). The average yield loss due to the suboptimal water availability $\left(\mathrm{YG}_{\mathrm{w}}\right)$ during the growth period was estimated as $8141 \mathrm{~kg} \cdot \mathrm{ha}^{-1}$, about $36.3 \%$ of the average simulated potential yield $\left(\mathrm{Y}_{\mathrm{p}}\right)$ across the states. The yield gaps due to water limitation were prominent at the locations with low cumulative precipitation over the crop growth period, such as in Kano (Figure S1). However, it narrowed down considerably at states with higher rainfall (Figure S1). The average actual yield gap (i.e., $\mathrm{YG}_{\mathbf{a}}$ ) across the 30 states was estimated as $10061 \mathrm{~kg} \cdot \mathrm{ha}^{-1}$ with the highest and lowest (14465 and $\left.2051 \mathrm{~kg} \cdot \mathrm{ha}^{-1}\right)$ in Akwa Ibom and the Sokoto States, respectively.

\section{$336 \quad$ 4. Discussion}

337 We investigated the relationship between climate variability and simulated yield gaps of cassava in Nigeria. 338 Random forests with extreme gradient boosting was performed for the state-level yields and yield gaps as the 339 dependent variable and precipitation, temperature, and radiation (during the crop growth period) as independent 340 variables. A multivariate linear regression with the same framework revealed that precipitation (negative slope) 341 and radiation (negative slope) significantly explained the spatial variability in simulated actual yield and the 342 observed yield (Table 3). These findings are also corroborated by Akinwumiju et al. (2020), who found that 343 cassava yield-sunshine hour and cassava yield-precipitation relationships are significant, unlike cassava344 temperature relationships. However, the negative linear relationship with precipitation could be attributed to the 345 decreasing radiation due to cloud cover changes in the presence of increased rainfall. Additionally, higher 346 precipitation could result in an increased amount of nitrogen leaching from the soil. Water-limited yield and 347 potential yield of cassava were significantly influenced by radiation during the crop growth period.

348 The observed yield had no significant relation with the temperature values in the crop growing cycle as was 349 revealed by the linear regression. However, the linear regression may not be able to disentangle nonlinear associations. Random forests, which captures the nonlinear relationships as a machine learning methodology highlight that the maximum temperature has the highest importance for observed yield. The linear regression however shows a significant relationship only with the radiation and precipitation amount. From a simplistic mechanistic perspective, we conduct the further inference using linear regression. This phenomenon could be ascribed to the higher radiation with ample precipitation within the crop growth period, which could facilitate higher crop biomass production, hence higher yield (through effects on maintenance respiration) (Akinwumiju et al., 2020; Ramarohetra et al., 2013; Boron et al., 2005; Sultan et al., 2005). Researchers have also reported that under the non-limiting condition of rainfall, attainable yield depends on solar radiation. Thus, it is a limiting factor for potential crop yield, especially in the humid regions of West Africa, due to the dense cloud covers during the rainy season (Srivastava et al., 2017; Sultan et al., 2005; Folberth et al., 2012).

360 We have plotted potential and water-limited cassava yield against the cumulated precipitation during the crop growth period (Figure 5). We obtained a biphasic pattern for the water-limited cassava yield, consisting of an exponential relationship between 370 and $1750 \mathrm{~mm}$ of precipitation and a decreasing plateau for the higher cumulative precipitation amounts. A decreasing trend plateaued around $2250 \mathrm{~mm}$ of cumulative precipitation during the crop growth period was obtained with potential cassava yield. However, the same phenomenon was reported in earlier studies in West African countries for maize and pearl millet (Srivastava et al., 2017; Boron et al., 2005). 


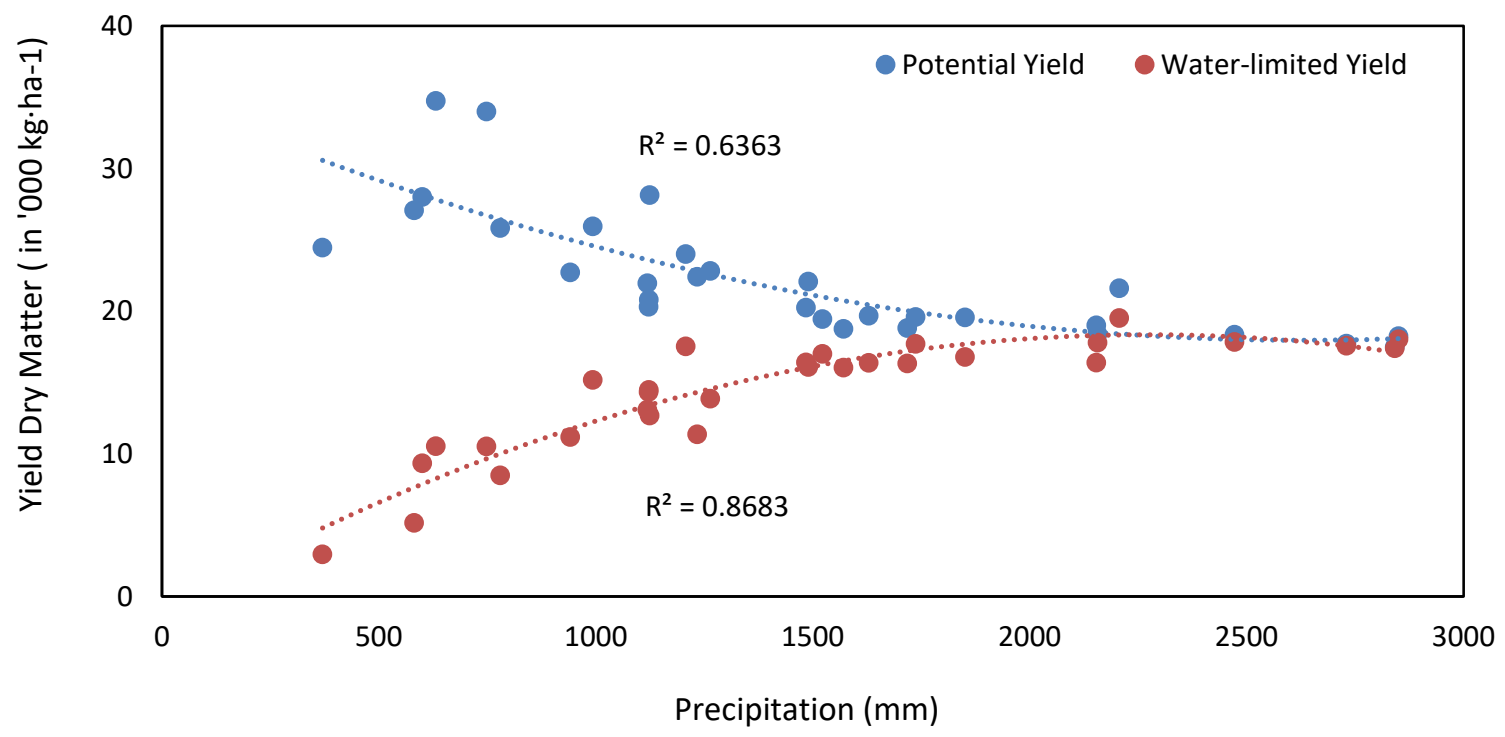

369 Figure 5. Relationship between simulated potential yield, water-limited cassava yields, and cumulated 370 precipitation amount (in $\mathrm{mm}$ ) during the crop growth period.

372 The model estimated large and variable gaps in cassava yield across the States. The average total yield gap was approximately $18202 \mathrm{~kg} \cdot \mathrm{ha}^{-1}$, with the maximum value of $31207 \mathrm{~kg} \cdot \mathrm{ha}^{-1}$ in Kano State. Also, the average yield gap due to water-limitation was $8141 \mathrm{~kg} \cdot \mathrm{ha}^{-1}$, with the highest value $\left(24215 \mathrm{~kg} \cdot \mathrm{ha}^{-1}\right)$ in Kano State, a savanna ecological zone characterized by a short rainy season (Akinwumiju et al., 2020). Similarly, cassava's average actual yield gap for the states was $10061 \mathrm{~kg} \cdot \mathrm{ha}^{-1}$, with the highest value $\left(14465 \mathrm{~kg} \cdot \mathrm{ha}^{-1}\right)$ in Akwa-Ibom State, a region characterized by favourable climatic conditions and well-drained conditions soil (Akinwumiju et al., 2020). Therefore, we suggest that improving crop management through nutrient application and soil water-loss reduction could help to minimize cassava yield gaps. The estimated highest untapped cassava yields $\left(\mathrm{YG}_{\mathrm{t}}\right)$ in States (such as

380 Kano, Bauchi, Gombo, and Kebbi) align clearly with a previous study (Akinwumiju et al., 2020). These states are 381 categorized as "suitable" to "very suitable" cultivable areas. Therefore, cassava cultivation would excel 382 adequately; hence profitable cassava production could be successfully undertaken on at least 60 million hectares of land in Nigeria.

384 The current study's estimated cassava yield gap, based on water limitation (i.e., with optimal fertilization and water 385 as the major growth-limiting factors), was consistent and within the reported yield gaps range reported elsewhere.

386 For example, Adiele et al. (2020) reported reducing the cassava yield gaps by 230\% under optimum fertilizer application in Edo, Cross River, and the Benue States in Nigeria. Another study (Fermont et al., 2009) estimated

388 a water-limited cassava yield gap (i.e., closing the yield gaps) by improving the soil fertility in Kenya and Uganda 389 (East Africa) ranged from an average difference of $6700 \mathrm{~kg} \cdot \mathrm{ha}^{-1}$ to a maximum of $7900 \mathrm{~kg} \cdot \mathrm{ha}^{-1} \mathrm{concerning}$ the 390 attainable yield.

391 Our study across 30 states estimated that nutrient management accounts for $55.3 \%$ of the total cassava yield gap, 392 while the remaining $44.7 \%$ is attributed to water limitation. The highest untapped water-limited yields were 393 estimated in States, such as Bauchi, Gombe, and Sokoto, characterized by the short rainy season, therefore posing 
394 a threat to the widely practised rainfed agriculture in Nigeria (Mbanasor et al., 2015; Ogunrinde et al., 2019).

395 However, farmers could use abundant renewable water resources to compensate for soil moisture deficits,

396 particularly in regions with a short rainy season. This scenario could be achieved by retaining a large percentage

397 of the annual runoff for irrigation purposes during the dry season (Akinwumiju et al., 2020). Thus, cassava

398 production should be targeted by suitable land allocation where viable irrigation infrastructure is available,

399 particularly in the northern part of Nigeria. Moreover, the nutrient-related constraints accounting for $>55 \%$ of the

400 untapped cassava potential yield demands effective on-farm management and soil fertility enhancement (organic

401 and inorganic fertilizer application), already practiced in some SSA countries (Aliyu et al., 2019; Ezui et al., 2015;

402 Edet et al., 2013). Compared to other SSA countries (such as Niger, Ghana, and Cameroon), increased cassava

403 yield has been attributed to effective on-farm management, fertile land allocation, and fertilizer application, where

404 required (Ezui et al., 2017; Kaweewong et al., 2013; Adjei-Nsiah et al., 2007). Whereas in Nigeria, the reverse is

405 the case. Here, local cassava varieties and nutrient-depleted soils are attributed to its cultivation, and the major

406 cassava production belt lacks the required on-farm management practices. Therefore, access to the irrigation

407 facilities (especially in regions with short rainy seasons, semi-arid regions) and newly improved cassava varieties

408 is imperative to improve the current cassava yield and production fertilizer application.

409 Our results showed that most northern states are better equipped to become leading cassava producers in Nigeria 410 under adequate crop management practices involving irrigation and soil fertility enhancement. We reached this 411 deduction because the northern states usually receive the highest radiation from their characteristic reduced cloud 412 cover, even at the peak of the rainy season. Another reason is that cassava production cost is lower in the north 413 than in the south, courtesy of available extensive, less competitive expanse of lands that could be made suitable 414 for cassava cultivation. Furthermore, considering the ongoing increasing rainfall trend in northern Nigeria 415 (Animashaun et al., 2020), more locations might gain a suitability advantage for rainfed cassava production with 416 time.

417 There were some limitations of the current study, highlighting the necessary improvements for further research.

418 Usually, large-scale assessments are confronted with the trade-off between the advantages of a large spatial study 419 coverage (useful for policymaking) (Ewert et al., 2015) and the disadvantage of low spatial accuracy at the farmer's 420 field level. The lack of detailed model calibration at a finer scale is a popular challenge for large-scale crop 421 modeling (Müller et al., 2017) because location-specific environmental and management data are usually 422 challenging to obtain consistently for large regions (Angulo et al., 2013). Because we also used the average yield 423 values of five cassava varieties to estimate the yield gaps for Nigeria, a future study can be structured by interacting 424 with local experts so that well-adapted cultivars specific to each state could be simulated.

425 Production systems were abstracted at the level of a single crop, ignoring possible interactions within crop 426 rotations. If cropping systems were analyzed instead, crop performance in a given simulation unit would result 427 from its performance in different rotations and under different inputs of resources. We did not consider the effect 428 of certain climatic extremes, such as the impact of intense heat during particular development stages, which may 429 lead to total (cereal) crop failure. To overcome this limitation, small-scale studies that incorporate more detailed 430 information (e.g., on-farming environments, management practices, variety distribution, and the socio-economic 431 context of farmers (especially cassava value chain) could be used. They would complement our assessment to 432 provide more detailed recommendations for specific local areas cases minimizing the gaps in cassava yield. 
433 The current study results have provided vital information on how the cassava yield gap could be closed with many

434 attendant economic benefits and food security in Nigeria. Furthermore, the outcome of this study could better

435 enlighten stakeholders and policymakers in Nigeria on the need to harness renewable resources (such as

436 precipitation) and nutrient management while adopting scientific innovations to optimize the vast expanse of lands

437 currently underutilized, especially in the north.

439 Table 3. Regression coefficients of multiple linear regression of simulated potential, water-limited, actual yield, 440 and observed yield with different climatic variables Maximum temperature (Tmax), Minimum temperature 441 (Tmin), Radiation (Rad), and Precipitation (Ppt). $\mathrm{R}^{2}$ represents the variance explained by regression models.

$$
\frac{\operatorname{Tmax}\left({ }^{\circ} \mathrm{C}\right)}{\text { coeff. } \quad \text {-value }} \frac{\operatorname{Tmin}\left({ }^{\circ} \mathrm{C}\right)}{\text { coeff. }} \text { p-value } \frac{\operatorname{Rad}(\mathrm{MJ} / \mathrm{m} 2)}{\text { coeff. } p \text {-value }} \quad \frac{\operatorname{Ppt}(\mathrm{mm})}{\text { coeff. } p \text {-value }} \stackrel{\mathrm{R} 2}{-}
$$

Observed yield

Actual yield (simulated)

Water-limited yield (simulated)

Potential yield (simulated)

Total Yield gap (potential yield - observed yield)

Actual Yield gap (water-limited yield - observed yield)

Water-limited Yield gap (potential yield - water-limited yield)

$\begin{array}{llll}-491.6 & 0.17 & -592.9 & 0.21 \\ -451.6 & 0.1 & -125.8 & 0.7 \\ -1174.1 & 0.13 & -959.1 & 0.34 \\ 150.3 & 0.82 & -1489.3 & 0.09 \\ 642.0 & 0.2 & -896.4 & 0.2 \\ -682.5 & 0.2 & -366.1 & 0.6 \\ 1324.4 & <0.01 & -530.3 & 0.31\end{array}$

\begin{tabular}{lllll}
-0.24 & 0.01 & -1.98 & $<0.01$ & 0.69 \\
-0.16 & 0.01 & -1.49 & $<0.01$ & 0.76 \\
-0.47 & 0.02 & -1.89 & 0.16 & 0.84 \\
0.35 & 0.04 & 0.81 & 0.48 & 0.91 \\
0.59 & $<0.01$ & 2.79 & $<0.01$ & 0.95 \\
-0.23 & 0.11 & 0.09 & 0.93 & 0.83 \\
0.82 & $<0.01$ & 2.71 & $<0.01$ & 0.98 \\
\hline
\end{tabular}

Table 4: Feature importance of simulated potential, water-limited, actual yield, and observed yield with different climatic variables Maximum temperature (Tmax), Minimum temperature (Tmin), Radiation (Rad), and Precipitation (Ppt). The feature importance is computed using random forests algorithm with extreme gradient boosting.

\begin{tabular}{|l|l|l|l|l|}
\hline & Tmax & Tmin & Rad & Ppt \\
\hline Observed yield & 699 & 395 & 182 & 114 \\
\hline Actual yield (simulated) & 603 & 393 & 157 & 120 \\
\hline Water limited yield (simulated) & 724 & 498 & 295 & 86 \\
\hline Potential yield (simulated) & 576 & 416 & 127 & 109 \\
\hline Total yield gap (potential yield - observed yield) & 475 & 406 & 172 & 99 \\
\hline $\begin{array}{l}\text { Actual yield gap (water-limited yield - observed } \\
\text { yield) }\end{array}$ & 619 & 349 & 225 & 117 \\
\hline $\begin{array}{l}\text { Water limited yield gap (potential yield - water } \\
\text { limited yield) }\end{array}$ & 521 & 386 & 138 & 132 \\
\hline
\end{tabular}



planting patterns in a cassava-based cropping system in South West Nigeria. Research Journal of Agriculture and Biological Sciences, 3, 13-20.

This study was designed to explore cassava yield potential under potential and water-limited conditions in 30 states of Nigeria. We gathered that the simulated growth and development of cassava conform with the corresponding observed values. Thus, the LINTUL5 model can be successfully used to simulate cassava's growth and yield and determine the effects of temperature, precipitation, and other variables on its yield in 30 states of Nigeria. Furthermore, nutrient limitations were found to be more pronounced than the water limitation on cassava yield gaps in 20 states out of 30 states studied in the current study. Radiation and precipitation are the predominant climatic variables that influence cassava yield. The results are based on linear regression and feature importance values from a nonlinear machine learning based method need to be considered in future. There is a high potential to improve the current cassava yield levels, provided farm interventions are made, emphasizing irrigation schemes in the areas characterized by the short rainy season and on nutrient and soil health management.

\section{Acknowledgments}

This research has been supported by the UPSCALERS project (grant no. AURG II-1-074-2016), German Federal Ministry of Education and Research (BMBF) in the framework funding measure "Soil as a Sustainable Resource for the Bioeconomy - BonaRes", project BonaRes (Modeule A): BonaRes Center for Soil Research, subproject 'Sustainable Subsoil Management - Soil3' (grant 031B0151A), and Deutsche Forschungsgemeinschaft (DFG, German Research Foundation), under Germany's Excellence Startegy - EXC2070-390732324. The authors also gratefully acknowledge the granted access to the "Bonna" cluster hosted by the University of Bonn."

\section{References}

3. Addiscott, T.M., Whitmore, A.P. (1991). Simulation of solute leaching in soils with different permeabilities. Soil Use Manage. 7, 94-102. Giller, K.E. (2020). Towards closing cassava yield gap in West Africa: Agronomic efficiency and storage root yield responses to NPK fertilizers. Field Crops Res. 253.

Allen, R.G., Pereira, L.S., Raes, D., Smith, M. (1998). Crop Evapotranspiration: Guidelines for Computing Crop Water Requirements. Irrigation \& Drainage Paper 56. UN-FAO, Rome, Italy, p. 301.

Akinwumiju, A.S., Adelodun, A.A., Orimoogunje, O.I. (2020). Agro-Climato-Edaphic Zonation of Nigeria for a Cassava Cultivar using GIS-Based Analysis of Data from 1961 to 2017. Scientific Reports. 10. 
6. Aliyu, I.A., Yusuf, A.A., Uyovbisere, E.O., Masso, C., Sanders, I.R. (2019). Effect of co-application of phosphorus fertilizer and in vitroproduced mycorrhizal fungal inoculants on yield and leaf nutrient concentration of cassava. PLOS One. 14, e0218969.

7. Adjei-Nsiah, S., Kuyper, T. W., Leeuwis, C., Abekoe, M. K., Giller, K. E. (2007). Evaluating sustainable and profitable cropping sequences with cassava and four legume crops: effects on soil fertility and maize yields in the forest/savannah transitional agro-ecological zones of Ghana. Field Crops Res. 103, 87-97.

8. Animashaun, I. M., Oguntunde, P. G., Olubanjo, O. O., Akinwumiju, A. S. (2020). Rainfall Analysis over Niger Central Hydrological Area, Nigeria: Variability, Trend and Change point detection. Scientific African, 8:e00419. DOI: 10.1016/j.envpol.2020.115545.

9. Angulo, C., Rötter, R., Trnka, N., Pirttioja, N., Gaiser, T., Hlavinka, P., Ewert, F. (2013). Characteristic 'fingerprints' of crop model responses to weather input data at different spatial resolutions. Eur J Agron. 49, 104-114.

10. Bamidele, F. S., Babatunde, R. O., Rasheed, A. (2008). Productivity analysis of cassava-based production systems in the Guinea savannah: Case study of Kwara State, Nigeria. American-Eurasian Journal of Scientific Research, 3, 33-39.

11. Baron, C., Sultan, B., Balme, M., Sarr, B., Traore, S., Lebel, T., Janicot, S., Dingkuhn, M. (2005). From GCM grid cell to agricultural plot: scale issues affecting modelling of climate impact. Phil. Trans. R. Soc.

12. Cock, J.H., Franklin, D., Sandoval, G., Juri, P. (1979). The ideal cassava plant for maximum yield. Crop Sci. 19, 271-279.

13. Chamberlain, J., Jayne, T.S., Headey, D. (2014). Scarcity amidst abundance? Reassessing the potential for cropland expansion in Africa. Food Policy, 48, 51-65.

14. de Araújo Visses, F., Sentelhas, P. C., Pereira, A. B. (2018). Yield gap of cassava crop as a measure of food security-an example for the main Brazilian producing regions. Food Security, 10, 1191-1202.

15. De Souza, A.P., Massenburg, L.N., Jaiswal, D., Cheng, S., Shekar, R., Long, S.P. (2017). Rooting for cassava: insights into photosynthesis and associated physiology as a route to improve yield potential. New

16. De Souza, A.P., Long, S.P. (2018). Toward improving photosynthesis in cassava: characterizing photosynthetic limitations in four current African cultivars. Food Energy Secur. https://doi.org/10.1002/fes3.130.

514 17. Echebiri, R.N., Edaba, M.E.I. (2008). Production and utilization of cassava in Nigeria: Prospects for food security and infant nutrition. PAT. 4, 38-52.

516 18. ECMWF. ERA5-Land hourly data from 1981 to present, Technical Report, ECMWF, 
19. Eke-Okoro, O., Njoku, D. (2012). A review of cassava development in Nigeria from 1940-2010. J. Agric. Bio. Sci. 7, 59-65.

20. Evans, L.T. (1993). Crop Evolution, Adaptation and Yield. Cambridge University Press, Cambridge.

21. Ewert, F., Rötter, R. P., Bindi, M., Webber, H., Trnka, M., Kersebaum, K.C., Olesen, J.E., van Ittersum, M.K., Janssen, S., Rivington, M., Semenov, M.A., Wallach, D., Porter, J.R., Stewart, D., Verhagen, J., et al. (2015). Crop modelling for integrated assessment of risk to food production from climate change. Environmental Modelling \& Software. 72, 287-303.

22. Ezui, K.S., Leffelaar, P.A., Franke, A.C., Mando, A., Giller, K.E. (2018). Simulating drought impact and

23. Ezui, K.S., Franke, A.C., Mando, A., Ahiabor, B.D.K., Tetteh, F.M., Sogbedji, J., Janssen, B.H., Giller, K.E. (2015). Fertilizer requirements for balanced nutrition of cassava across eight locations in West Africa. Field Crops Res. 185, 69-78.

24. Ezui, K. S., et al. (2017). Understanding cassava yield response to soil and fertilizer nutrient supply in

25. Edet, M., Tijani-Eniola, H., Okechukwu, R. (2013). Residual efects of fertilizer application on growth and yield of two cassava varieties in Ibadan, South-Western Nigeria. Afr. J. Root Tuber Crops. 10, 3340.

27. FAO. (2010). FAOSTAT Statistical Database. Food and Agricultural Organization of the UN, Rome.

28. Faye, B., Webber, H., Diop, M., Mbaye, M., Owusu-Sekyere, J.D., Naab, J.B., Gaiser, T. (2018). Potential impact of climate change on peanut yield in Senegal, West Africa. Field Crop. Res. 219, 148-159.

29. Fermont, A.M., van Asten, P.J.A., Tittonell, P., van Wijk, M.T., Giller, K.E. (2009). Closing the cassava yield gap: An analysis from smallholder farms in East Africa. Field Crops Res. 112, 24-36. crop growth model for sub-Saharan Africa: model setup, evaluation, and estimation of maize yields. Agric. Ecosyst. Environ. 151, 21-33. (2013). Modeling biopore effects on root growth and biomass production on soils with pronounced subsoil clay accumulation. Ecol. Model. 256, 6-15. 
33. Kaweewong, J., Kongkeaw, T., Tawornprek, S., Yampracha, S., Yost, R. (2013). Nitrogen requirements of cassava in selected soils in Thailand. J. Agr. Rural Dev. Trop. Subtrop. 114, 13-19.

34. Lobell, D. B., Cassman, K. G., Field, C.B. (2019). Crop yield gaps: their importance, magnitudes, and causes. Annual review of environment and resources, 34.

35. Mbanasor, J.A., Nwachukwu, I.N., Agwu, N.M., Onwusiribe, N. C. (2015). Impact of climate change on the productivity of cassava in Nigeria. J. Agric. Environ. Sci. 4, 138-147.

36. Müller, C., Elliott, J., Chryssanthacopoulos, J., Arneth, A., Balkovic, J., Ciais, P., Deryng, D., Folberth, C., Glotter, M., Hoek, S., Iizumi, T., Izaurralde, R.C., Jones, C., Khabarov, N., et al. (2017). Global gridded crop model evaluation: Benchmarking, skills, deficiencies and implications. GMD. 10, 14031422.

37. Ogunrinde, A.T., Oguntunde, P.G., Akinwumiju, A.S., Fasinmirin, J.T. (2019). Analysis of recent changes in rainfall and drought indices in Nigeria, 1981-2015. Hydrol. Sci. J. 64, 1755-1768.

38. Otekunrin, O. A., Sawicka, B. (2019). Cassava, a 21st Century Staple Crop: How can Nigeria Harness Its Enormous Trade Potentials? Acta Scientific Agriculture, 3.

39. Ramarohetra, J., Sultan, B., Baron, C., Gaiser, T., Gosset, M. (2013). How satellite rainfall estimates errors may impact rain-fed cereal yield simulation in West Africa? Agric. For. Meteorol. 180, 118-131.

40. Rahman, S., Awerije, B.O. (2016). Exploring the potential of cassava in promoting agricultural growth in Nigeria. J. Agric. Rural Dev. Trop. 117, 149-163.

41. Rawls, W.J., Ahuja, L.R., Maidment, D.R. (1993). Handbook of Hydrology. McGraw-Hill, p. 1442.

42. Reidsma, P., Ewert, F., Lansink, A.O., Leemans, R. (2010). Adaptation to climate change and climate variability in European agriculture: the importance of farm level responses. Eur. J. Agron. 32, 91-102.

43. Sarr, P.S., Araki, S., Njukwe, E. (2013). Interactions between cassava varieties and soil characteristics in crop production in eastern Cameroon. Afri. Study Monogr. 34, 187-202.

44. Srivastava, A.K., Ceglar, A., Zeng, W., Gaiser, T., Mboh, C.M., Ewert, F. (2020). The Implication of Different Sets of Climate Variables on Regional Maize Yield Simulations. Atmosphere, 11, 180.

45. Srivastava, A.K., Mboh, C.M., Faye, B., Gaiser, T., Kuhn, A., Ermias, E., Ewert, F. (2019). Options for Sustainable Intensification of Maize Production in Ethiopia. Sustainability. 11, 1707.

46. Srivastava, A.K., Mboh, C.M., Gaiser, T., Ewert, F. (2017). Impact of climatic variables on the spatial and temporal variability of crop yield and biomass gap in Sub-Saharan Africa-a case study in Central Ghana. Field Crop. Res. 203, 33-46. 
601

602

603

48. Trawally, D., Webber, H., Agyare, W.A., Fosu, M., Naab, J., Gaiser, T. (2015). Effect of heat stress on two maize varieties under irrigation in Northern Region of Ghana. Int. J. Biol. Chem. Sci. 9, 1571-1587.

49. Ugwu, B. (1996). Increasing cassava production in Nigeria and prospects for sustaining the trend. Outlook on Agriculture. 25, 179-185.

50. Van Ittersum, M.K., Cassman, K.G., Grassini, P., Wolf, J., Tittonell, P., Hochman, Z. (2013). Yield gap analysis with local to global relevance-A review. Field Crop. Res. 143, 4-17.

51. van Bussel, L.G.J., Grassini, P., Van Wart, J., Wolf, J., Claessens, L., Yang, H., Boogaard, H., de Groot, H., Saito, K., Cassman, K.G., van Ittersum, M.K. (2015). From field to atlas: upscaling of locationspecific yield gap estimates. Field Crop. Res. 177, 98-108.

52. Wolf, J. (2012). User Guide for LINTUL5: Simple Generic Model for Simulation of Crop Growth Under Potential, Water Limited and Nitrogen, Phosphorus and Potassium Limited Conditions. Wageningen UR, pp. 1-63.

53. Yu, Q. et al. (2010). A cultivated planet in 2010: Part-2 The global gridded agricultural production maps. Earth Syst. Sci. Data 12, 3545-3572. 


\section{Supplementary Files}

This is a list of supplementary files associated with this preprint. Click to download.

- Supplementary.docx 